\title{
RNA Virus in Allomyces arbuscula: Ultrastructural Localization During the Life-cycle
}

\author{
By U.-P. ROOS, E. W. KHANDJIAN AND G. TURIAN \\ Laboratoire de Microbiologie, Département de Biologie végétale, \\ University of Geneva, I2I I Geneva 4, Switzerland
}

(Received I9 November 1975)

\begin{abstract}
SUMMARY
Strain Bali I of Allomyces arbuscula is infected with a RNA virus; strain North Carolina is not. The virus appears to be avirulent, for strain Bali I showed no signs of pathogenicity. Virus aggregates occurred mostly in the cytoplasm during different stages of the gametophytic and sporophytic generations. Small intranuclear aggregates were found only in differentiating gametophytic hyphae and immature gametangia. In motile cells (gametes and zoospores) the aggregates are exclusively contained within the nuclear cap. This represents a reliable mechanism of transmission throughout the life-cycle.
\end{abstract}

\section{INTRODUCTION}

Viruses or virus-like particles (VLP) have been demonstrated in various species of fungi, mainly of the classes Deuteromycetes, Ascomycetes and Basidiomycetes (Lemke \& Nash, 1974). The common features of fungal viruses that have been characterized biophysically are their small size, their polyhedral or spherical shape, and their content of doublestranded RNA (reviewed by Lemke \& Nash, 1974).

Information about the transmission of fungal viruses from generation to generation is scant. The detection, by Banks et al. (1969), of VLP in several penicillin-producing strains of Penicillium chrysogenum derived from the same parent strain suggested transmission via conidia. The persistence of viruses or VLP in single spore isolates has been reported for several species of Penicillium (Crosse \& Mason, I974; Hollings \& Stone, I97I ; Lhoas, 197I) and the presence of such particles in conidia has been demonstrated (Hooper et al., 1972; Sansing et al., 1973). Spreading of the 'die-back disease' of Agaricus bisporus may occur via basidiospores (Schisler, Sinden \& Sigel, 1967) and the presence of virus particles in mycelium, carpophore tissues, basidiospores and their germ tubes has been documented by Dielemanvan Zaayen \& Igesz (1969) and Dieleman-van Zaayen (I972). However, details about the cellular localization of viruses or VLP at different stages of the life-cycle were not reported in any of these cases.

Following the discovery of aggregates of VLP in undifferentiated gametophytic hyphae of one of our laboratory strains of Allomyces arbuscula Butler, we reported their general description and partial characterization (Khandjian et al., 1974). Additional biochemical and biophysical data led us to consider that these particles were RNA viruses rather than only virus-like (Khandjian, Roos \& Turian, 1975). Furthermore, we realized, in the course of an unrelated study, that in mature gametes the virus particles were preferentially localized in the mass of ribosomes making up the nuclear cap. This suggested a remarkable mechanism of transmission through sexual and asexual generations and we decided to investigate the phenomenon in more detail. 


\section{METHODS}

Strains and stock cultures. Strains Bali I (Noack I0I.33) and North Carolina (Hatch I04.36) of $A$. arbuscula were originally obtained from the Centraalbureau voor Schimmelcultures, Baarn, The Netherlands. Stock cultures were maintained on half-strength YpSs agar slants (Emerson, I94I). This medium contained (g/l distilled water): powdered yeast extract, 2.0; soluble starch, $7.5 ; \mathrm{K}_{2} \mathrm{HPO}_{4}, 0.5 ; \mathrm{MgSO}_{4} .7 \mathrm{H}_{2} \mathrm{O}, 0.25 ;$ agar, 20.0.

Experimental cultures, gametophyte. Cultures were incubated at $25{ }^{\circ} \mathrm{C}$ unless otherwise stated. Vegetative mycelia of strain Bali I were produced in GCY liquid medium (Turian, I963) or on half-strength YpSs agar medium following inoculation with meiospores released from mature resistant sporangia. GCY medium contained $(\mathrm{g} / \mathrm{l})$ : glucose, $5 \cdot 0$; caseine hydrolysate, 3.0; yeast extract, $0 . \mathrm{I} ; \mathrm{NaCl}, 0 . \mathrm{I} ; \mathrm{CaCl}_{2} .2 \mathrm{H}_{2} \mathrm{O}, 0 . \mathrm{I} ; \mathrm{FeCl}_{3} .6 \mathrm{H}_{2} \mathrm{O}, 0.02$; $\mathrm{K}_{2} \mathrm{HPO}_{4}, \mathrm{I} \cdot 0 ; \mathrm{MgSO}_{4} \cdot 7 \mathrm{H}_{2} \mathrm{O}, 0 \cdot 2$. Cultures in this medium were incubated for between I and 3 days on a reciprocal shaker in the dark. Cultures on YpSs agar were incubated for 7 days. Sexual differentiation of mycelia grown in GCY liquid medium was induced by transfer to a dilute salt solution (Machlis \& Ossia, I953).

Vegetative hyphae and the various stages of gametogenesis were also obtained by growing either of the two strains on sterile fragments of hempseed in half-strength salt solution in Petri dishes for 24 or $42 \mathrm{~h}$ at $25^{\circ} \mathrm{C}$.

Strain North Carolina was incubated on YpSs agar for 6 days and the final stages of sexual differentiation were obtained by immersion in half-strength salt solution.

Experimental cultures, sporophyte. Small blocks cut from a 7-day-old gametophytic culture on YpSs agar were immersed in half-strength salt solution for $2 \mathrm{~h}$. Gametes and zygotes were collected by low speed centrifuging and incubated for $2 \mathrm{~h}$ in YpSs liquid medium. These cultures yielded encysted zygotes and sporophytic germlings.

Young vegetative mycelia were produced by inoculating GCY liquid medium or YpSs agar with gametes released in sterile distilled water, and incubating for $22 \mathrm{~h}$ at $25^{\circ} \mathrm{C}$ or I $6 \mathrm{~h}$ at room temperature $\left(20\right.$ to $22{ }^{\circ} \mathrm{C}$ ), respectively.

Differentiation of zoosporangia (mitosporangia) was induced by immersing blocks of the mycelium grown for $16 \mathrm{~h}$ on YpSs agar in half-strength salt solution. Cleaving resistant sporangia and released meiospores were obtained by immersing resistant sporangia from a 3-month-old culture on YpSs agar in sterile distilled water for $4 \mathrm{~h}$. Resistant sporangia and meiospores were collected on a Millipore filter (pore size $\mathrm{I} \cdot 2 \mu \mathrm{m}$ ).

Electron microscopy. Vegetative gametophytic mycelia grown on YpSs agar were fixed as described by Khandjian et al. (1974). Gametophytic mycelia grown in GCY liquid medium or differentiated in salt solution were fixed for $\mathrm{I} h$ at room temperature in 2 or $3 \%(\mathrm{v} / \mathrm{v})$ glutaraldehyde in salt solution, final $\mathrm{pH}$ 6.8. Postfixation was under similar conditions in I or $2 \%$ ? $(\mathrm{w} / \mathrm{v})$ osmium tetroxide. Encysted zygotes, young sporophytic mycelia and differentiated zoosporangia were fixed for 15 min each in $2 \%(\mathrm{v} / \mathrm{v})$ glutaraldehyde and in $2 \%(\mathrm{w} / \mathrm{v})$ osmium tetroxide under identical conditions. Resistant sporangia and meiospores were fixed for $30 \mathrm{~min}$ each in similarly prepared $2 \%(\mathrm{v} / \mathrm{v})$ glutaraldehyde and $\mathrm{I} \%(\mathrm{w} / \mathrm{v})$ osmium tetroxide.

Following three rinses in distilled water, the material was prestained in an aqueous $2 \%$ $(\mathrm{w} / \mathrm{v})$ solution of uranyl acetate, preceded if necessary by embedding in $\mathrm{I} \%(\mathrm{w} / \mathrm{v})$ agar. After dehydration in ethanol, the material was embedded in Epon or in Spurr's (1969) medium.

Serial sections were cut with glass or diamond knives on a Reichert OmU-2 ultramicrotome, placed on 75-mesh or single-hole grids coated with Formvar and carbon, and post- 


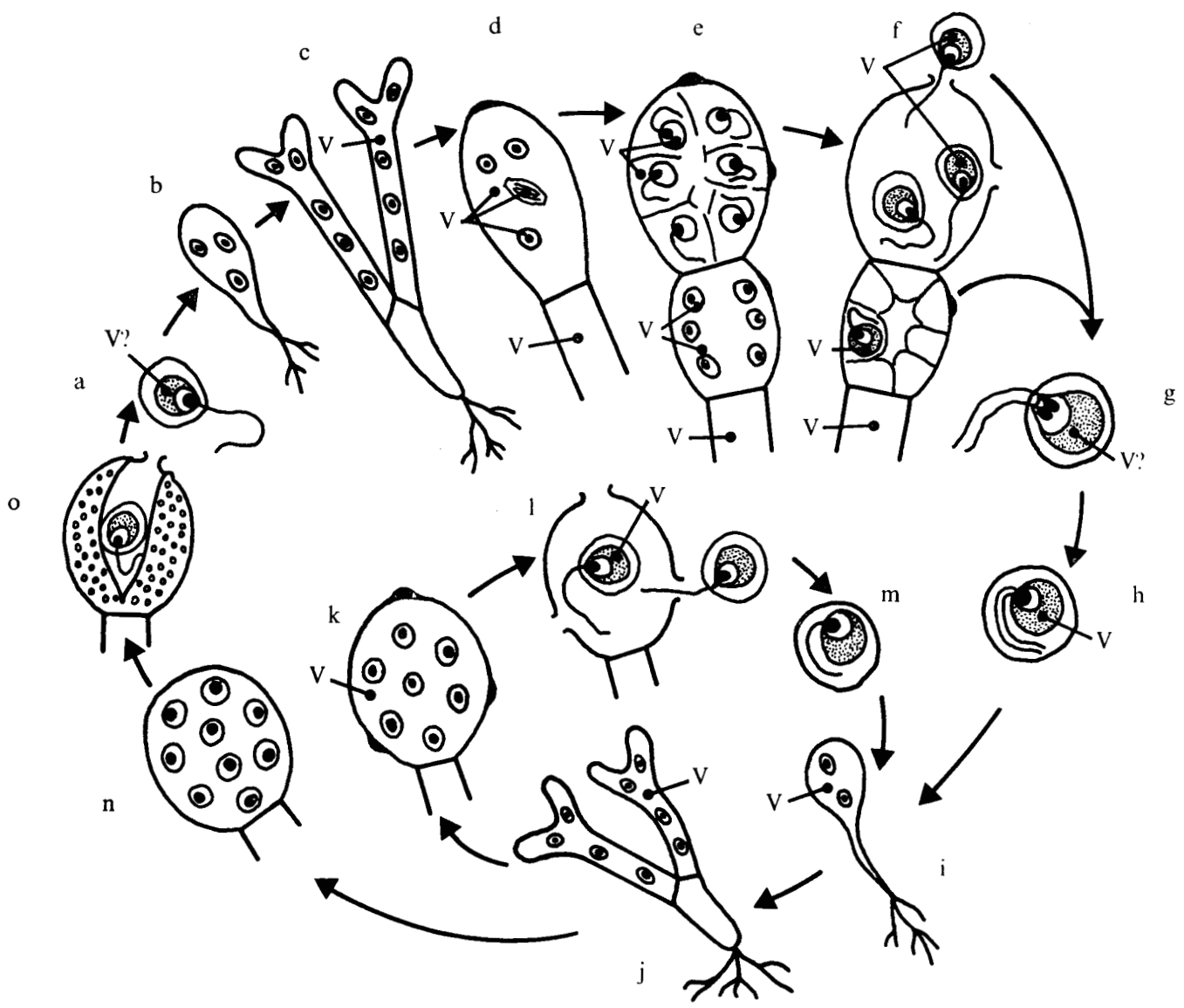

Fig. I. Semi-diagrammatic representation of the life cycle of $A$. arbuscula. Not all the stages are drawn to scale. $V$ designates the observed cellular localization of virus particles at different stages. $V$ ? indicates the expected localization of the virus in stages we examined, but where we did not observe it. a, Haploid meiospore; b, gametophytic germling; c, undifferentiated gametophytic hyphae; d, pre-cleavage female gametangium; e, cleaving female and pre-cleavage male gametangium; $\mathrm{f}$, releasing female and cleaved male gametangium; g, zygote after karyogamy; h, encysted zygote with resorbed flagella; $i$, sporophytic germling; $j$, undifferentiated sporophytic hyphae; $\mathrm{k}$, pre-cleavage zoosporangium (mitosporangium); 1, mature zoosporangium releasing diploid mitospores; $\mathrm{m}$, encysted mitospore; $\mathrm{n}$, pre-cleavage resistant sporangium; $\mathrm{o}$, mature resistant sporangium releasing haploid meiospores.

stained with uranyl acetate (Watson, 1958) and lead citrate (Reynolds, I963). The sections were examined at $60 \mathrm{kV}$ in an AEI EM 6B electron microscope.

\section{RESULTS}

Serial sections of vegetative hyphae and gametangia of strain North Carolina at various stages of development were examined. In addition, I59 mature gametes in I7 different gametangia were systematically investigated. Virus particles were not observed in any of these sections. In sections of strain Bali I we consistently found virus particles in the many gametophytic and sporophytic cultures prepared and fixed at different times over the past 

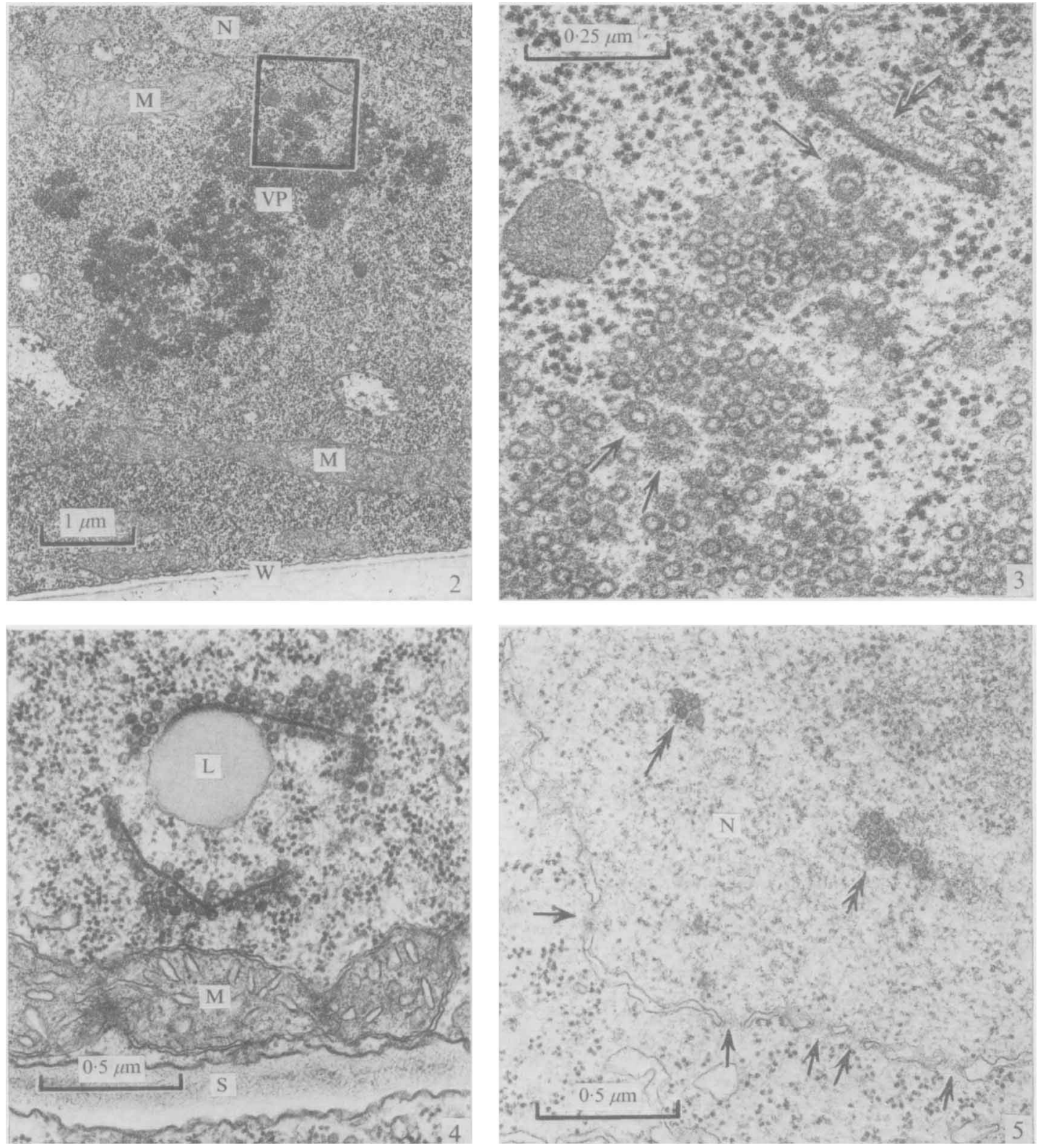

Fig. 2. Large, cytoplasmic aggregate of virus particles (VP) in an undifferentiated gametophytic hypha (c, Fig. I). M, Mitochondrion; N, nucleus; W, hyphal wall.

Fig. 3. The area outlined in Fig. 2 at higher magnification. Whereas most virus particles are empty, a few contain an electron-opaque core. Three particles are enveloped (single arrowed). Note the profile of a double membrane near the aggregate (double arrowed).

Fig. 4. Cytoplasmic aggregates of virus particles in a pre-cleavage male gametangium (e, Fig. I), associated with double membranes and a lipid droplet (L). M, Mitochondrion; S, gametangial septum.

Fig. 5. Small, intranuclear aggregates of virus particles (double arrowed) in a pre-cleavage male gametangium (e, Fig. I). N, Nucleus. Compare the diameter of the nuclear pores (single arrowed) with the virus particles. 
two years. However, viruses were not always equally abundant. We found large aggregates in sections of some mycelia, but in other cases a thorough examination of many serial sections revealed only one or a few small aggregates. The stages of the life-cycle for which we could ascertain the presence of the virus are identified in Fig. I. There was no macroscopic or microscopic evidence of pathogenicity nor any other physiological or morphological disorder in strain Bali $\mathrm{I}$. The growth rate of sporophytic mycelia on YpSs medium was comparable for both strains and their development was as similar as can be expected, considering their different origin and history (cf. Emerson, I94I).

\section{Viruses in the gametophyte of strain Bali $\mathrm{I}$}

Virus particles in undifferentiated hyphae were localized exclusively in the cytoplasm (Fig. 2). We never observed single particles. The virus always occurred in aggregates, often of considerable size (Figs. 2 and 3). Paracrystalline arrays with a regular spacing of approximately $40 \mathrm{~nm}$ from centre to centre of adjacent particles were frequently evident in large aggregates (Fig. 3). Whereas most viruses appeared empty, some had an electron-opaque core and, exceptionally, an envelope enclosed one or a few particles (Fig. 3).

Virus aggregates apparently occurred at random throughout the hyphae, except at the apex. The particles were an integral part of the cytoplasm and were never observed in vacuoles or vesicles, although sheet-like elements, having the profile of opposed double membranes in cross-sections, were sometimes associated with these aggregates (Figs. 2, 3 and 4). In senescent parts of hyphae, the aggregated virus occurred in the vacuolated spaces.

Hyphae in the early stages of gametogenesis, i.e. from the first apical swelling ('club' stage) to the formation of the second septum, and immature gametangia, which were forming flagella and beginning to cleave at the time of fixation, occasionally contained intranuclear virus particles in addition to cytoplasmic aggregates (Figs. 5 to 8). Intranuclear aggregates, which always consisted of fewer particles than those in the cytoplasm, occurred in both interphase nuclei and the less frequently encountered mitotic nuclei (Figs. 5 and 6). Intranuclear virus particles appeared to be embedded in an electron-opaque matrix (Figs. 5,6 and 8). Senescing support hyphae of pre- and post-cleavage gametangia also contained both cytoplasmic and intranuclear virus.

Efforts to localize the virus in post-cleavage gametangia, at the stage when the ribosomes aggregate to form the nuclear cap, were unsuccessful, but in mature and released gametes the virus aggregates occurred exclusively in fully formed nuclear caps (Figs. 9 and ro).

\section{Viruses in the sporophyte of strain Bali $\mathrm{I}$}

In encysted zygotes, which still contained an intact nuclear cap, the virus particles were localized in the nuclear cap, as in mature gametes (Fig. I I). However, germlings, which had ribosomes dispersed in the cytoplasm, contained aggregates of the virus in the cytoplasm (Figs. I 2 and I3), and the same was true for undifferentiated hyphae (Fig. I4), pre-cleavage and cleaving mitosporangia (Figs. 15 and I6), and support hyphae. As in the gametophyte, double membranes were sometimes associated with the virus. In mature mitospores, the virus was exclusively localized in the nuclear cap (Fig. 17).

We also examined serial sections of several cleaving and post-cleavage resistant sporangia and of a number of released meiospores, but found no virus, although an apparently aborted mitosporangium of the same culture contained aggregates of particles of the appropriate dimensions. 

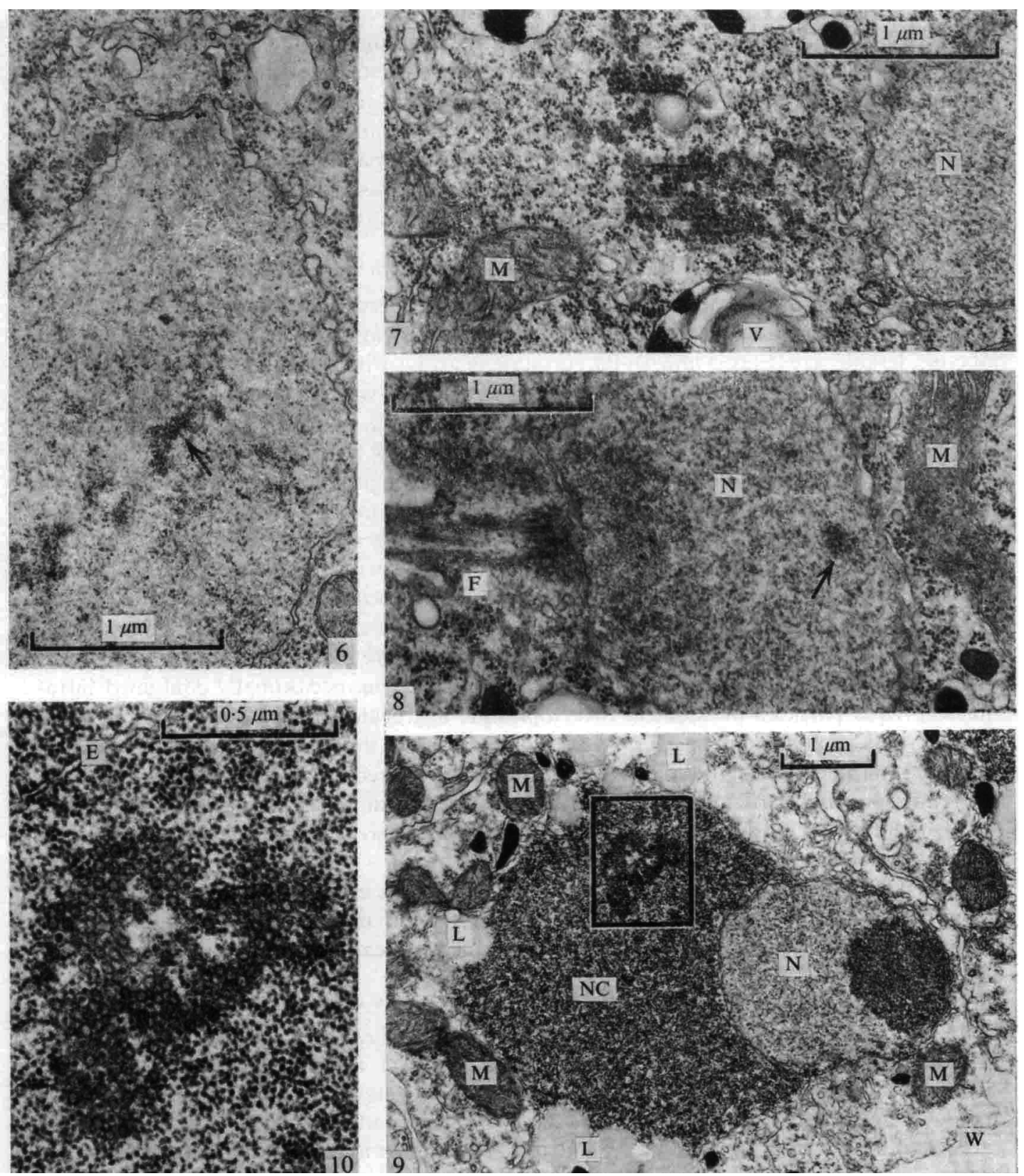

Fig. 6. Virus particles (arrowed) in a mitotic nucleus of a pre-cleavage male gametangium.

Fig. 7. Cytoplasmic aggregate of virus particles in a cleaving male gametangium (flagella present but not shown) (transition from e to f, Fig. 1). M, Mitochondrion; N, nucleus; V, vacuole.

Fig. 8. Intranuclear virus particles (arrowed) in a female gametangium at a stage similar to that of Fig. 7 (e, Fig. I). F, Flagellum; M, mitochondrion; N, nucleus.

Fig. 9. Aggregate of virus particles (outlined) in the nuclear cap (NC) of a mature female gamete (f, Fig. I). L, Lipid droplets; M, mitochondrion; N, nucleus with nucleolus; W, gametangial wall.

Fig. Io. The area outlined in Fig. 9 at higher magnification. E, Envelope of the nuclear cap. 

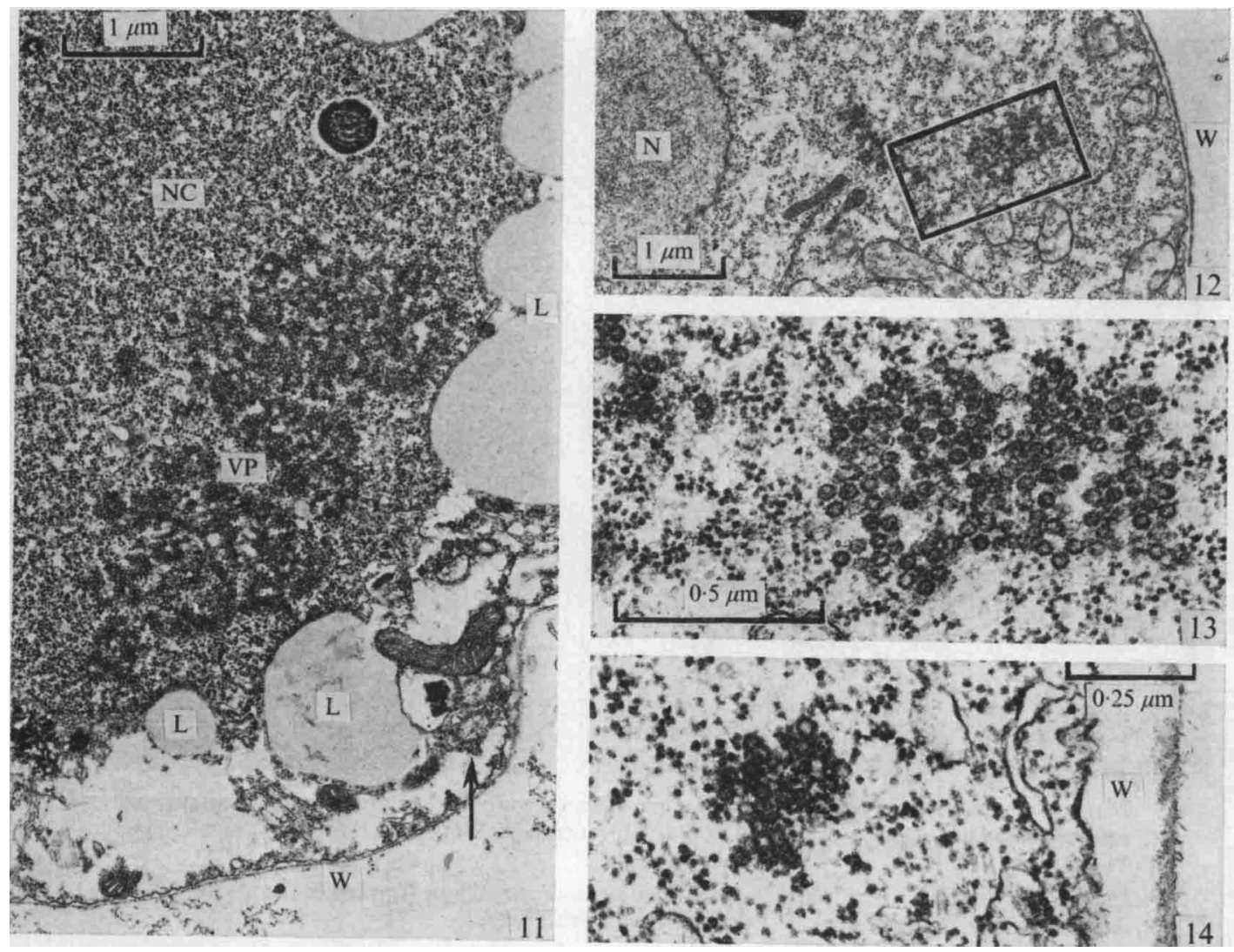

Fig. I I. Aggregate of virus particles (VP) in the still intact nuclear cap (NC) of an encysted zygote (h, Fig. r). The arrow points to the two obliquely sectioned resorbed flagella. L, Lipid body; $\mathrm{W}$, cyst wall.

Fig. 12. Cytoplasmic aggregates of virus particles (outlined) in a sporophytic germling (i, Fig. I). $\mathrm{N}$, Nucleus; W, cell wall.

Fig. 13. The area outlined in Fig. I 2 at higher magnification.

Fig. I4. Aggregate of virus particles in an undifferentiated sporophytic hypha (j, Fig. I). W, Hyphal wall.

\section{DISCUSSION}

Fungi infected by viruses or containing VLP exhibit degrees of virulence ranging from apparent latency to overt lysis (Lemke \& Nash, 1974). Diseased cultures of the cultivated mushroom, Agaricus bisporus, show symptoms such as sparse growth of mycelium, suppression of development, rapid necrosis, or dwarfing (Schisler et al., 1967). Borré et al (197I) reported the occurrence of lytic plaques in colonies of virus-infected Penicillium citrinum and $P$. variabile. In many other cases, however, no apparent physiological, morphological, or cytological anomalies were observed in infected mycelia (Border et al., 1972; Crosse \& Mason, 1974; Hooper et al., I972).

When attempting to assess cytological evidence of virus-induced degeneration or necrosis in fungi one must bear in mind that old portions of hyphae in the centre of a colony undergo natural senescence and disintegration. We examined mainly serial longitudinal sections of hyphae and gametangia so that no mistake was possible about whether we were studying 

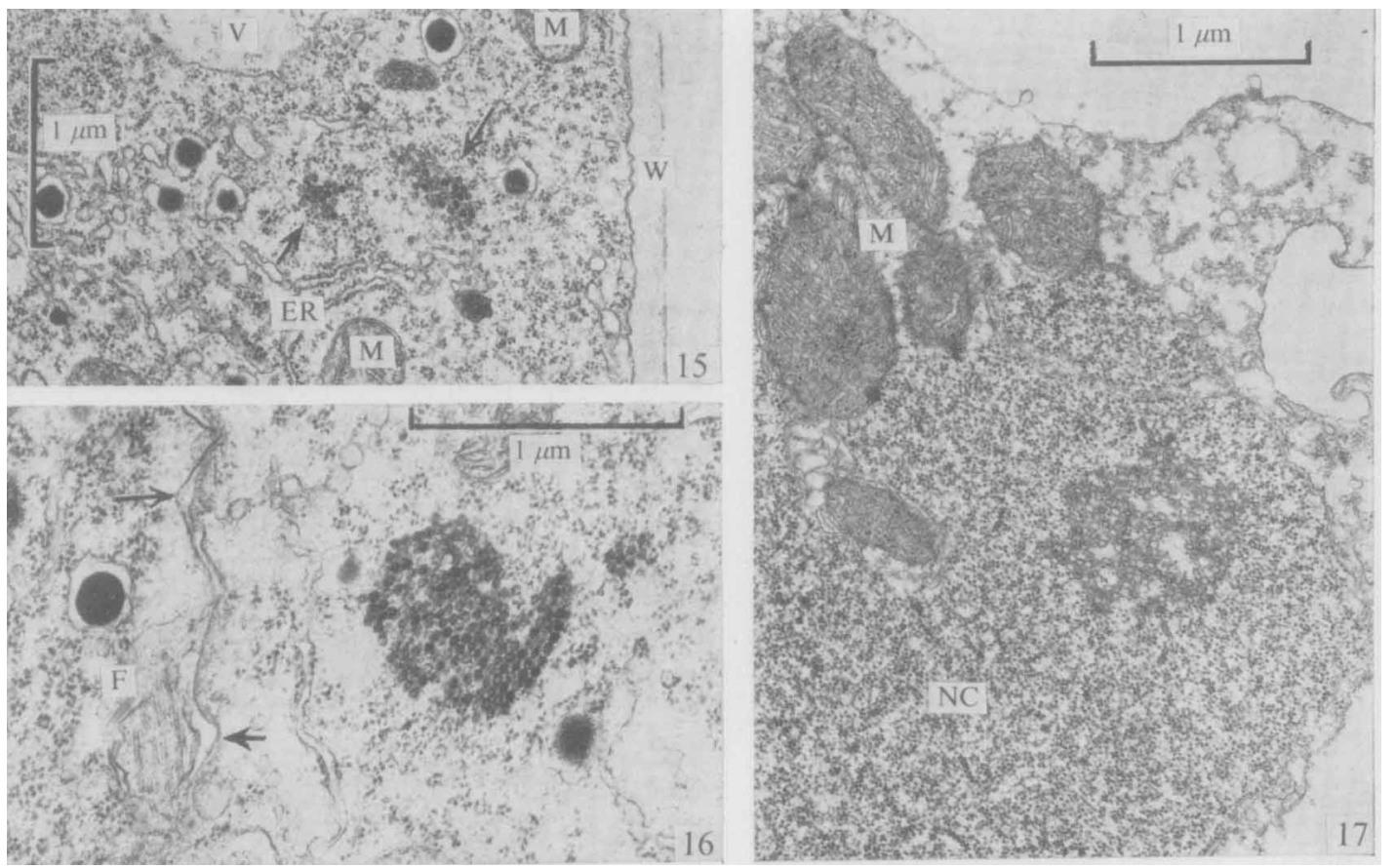

Fig. 15. Cytoplasmic aggregates of virus particles (arrowed) in a pre-cleavage zoosporangium (mitosporangium) (k, Fig. I). ER, Endoplasmic reticulum; M, mitochondrion; V, small vacuole; $\mathrm{W}$, sporangial wall.

Fig. 16. Aggregate of virus particles in a cleaving zoosporangium (transition from k to 1, Fig. 1). A cleavage furrow is arrowed. F, Obliquely sectioned flagellum.

Fig. 17. Aggregate of virus particles in the nuclear cap (NC) of a mature zoospore (mitospore) (1, Fig. I). M, Mitochondrion.

living or senescent parts. There was no overt cytopathological disorder in the infected strain Bali $\mathrm{I}$. Moreover, this strain is routinely used for various investigations in this laboratory (e.g. Ojha \& Turian, I97I ; Ojha, Dutta \& Turian, I975), and it develops all the stages of the life-cycle.

Border et al. (1972) and Crosse \& Mason (1974) reported that virus particles or VLP were absent from the hyphal tips of several infected Penicillium species. In older portions of the hyphae the virus aggregates were bound by a single membrane and, even further towards the base, the particles were contained in vacuoles (Border et al., 1972). Other investigators have also described associations of virus particles or VLP with cellular membranes, in the form of membrane-bound single particles or aggregates, or of particle-containing vacuoles (Dieleman-van Zaayen, 1972; Hirano, Lindegren \& Bang, 1962; Hooper et al., 1972; Metitiri \& Zachariah, 1972; Yamashita, Doi \& Yora, 1973). Double membranes of the kind we observed in $A$. arbuscula have, to our knowledge, not been reported. They are not a consistent feature of infected mycelia, nor are envelopes enclosing one or a few particles (Fig. 3; cf. Khandjian et al., 1974), and neither is typical for any part of the hyphae, old or young. The significance of these structures remains obscure.

Since the virus of $A$. arbuscula is predominantly cytoplasmic, its occasional presence in the nuclei is puzzling. Whether this is in some way related to the multiplication of the virus remains an open question. 
The most striking aspect of the Allomyces virus is its localization in the nuclear cap of motile cells. Although we could not document this for the haploid meiospores, we have little doubt that the same relationship applies as for gametes and diploid mitospores (Fig. I). The inclusion in the nuclear cap suggests a strong affinity of the virions for the ribosomes, which is possibly a consequence of their ribonucleoprotein nature. In any event, this association with a vital component represents a remarkably reliable mechanism of transmission throughout the life-cycle (Fig. I).

We thank Miss Sara Mastelli for competent technical assistance.

\section{REFERENCES}

Banks, G. T., Buck, K. W., Chain, E. B., Darbyshire, J. E. \& Himmelweit, F. (1969). Virus-like particles in penicillin producing strains of Penicillium chrysogenum. Nature, London 222, 89-90.

Border, D. J., Buck, K. W., Chain, E. B., Kempson-Jones, G. F., LhoAs, P. \& Ratti, G. (i972). Viruses of Penicillium and Aspergillus species. Biochemical Journal $127,4 \mathrm{P}-6 \mathrm{P}$.

Borré, E., Morgantini, L. E., Ortali, V. \& Tonolo, A. (1971). Production of lytic plaques of viral origin in Penicillium. Nature, London 229, 568-569.

Crosse, R. \& MAson, P. J. (I974). Virus-like particles in Penicillium chrysogenum. Transactions of the British Mycological Society 62, 603-634.

Dieleman-van ZaAYen, A. (1972). Intracellular appearance of mushroom virus in fruiting bodies and basidiospores of Agaricus bisporus. Virology 47, 94-104.

Dieleman-van ZAAYen, A. \& Igesz, O. (1969). Intracellular appearance of mushroom virus. Virology 39, I47-152.

EMERSON, R. (194I). An experimental study of the life cycles and taxonomy of Allomyces. Lloydia 4, 77-I 44.

Hirano, T., Lindegren, C. C. \& BANG, Y. N. (I962). Electron microscopy of virus-infected yeast cells. Journal of Bacteriology 83, 1363-1364.

Hollings, M. \& Stone, O. M. (I971). Viruses that infect fungi. Annual Review of Phytopathology 9, 93-11 8.

Hooper, G. R., Wood, H. A., Myers, R. \& Bozarth, R. F. (1972). Virus-like particles in Penicillium brevicompactum and $P$. stoloniferum hyphae and spores. Phytopathology 62, 823-825.

Khandian, E. W., Roos, U.-P., Timberlake, W. E., Eder, L. \& Turian, G. (I974). RNA virus-like particles in the Chytridiomycete Allomyces arbuscula. Archives of Microbiology 1or, 35 I-356.

Khandian, E. W., Roos, U.-P. \& Turian, G. (I975). Mycovirus d'Allomyces. Pathologia et microbiologia 42, 250-25I.

Lemke, P. A. \& NASH, C. H. (1974). Fungal viruses. Bacteriological Reviews 38, 29-56.

LhoAs, P. (I971). Transmission of double-stranded RNA viruses to a strain of Penicillium stoloniferum through heterokaryosis. Nature, London 230, 248-249.

Machlis, L. \& Ossia, E. (1953). Maturation of the meiosporangia of Euallomyces. I. The effect of cultural conditions. American Journal of Botany 40, 358-365.

Metitiri, P. O. \& Zachariah, K. (I972). Virus-like particles and inclusion bodies in penicillus cells of a mutant of Penicillium. Journal of Ultrastructure Research 40, 272-283.

OJHA, M. \& TuRIAN, G. (1971). Interspecific transformation and DNA characteristics in Allomyces. Molecular and General Genetics 112, 49-59.

Ojha, M., Dutta, S. K. \& Turian, G. (1975). DNA nucleotide sequence homologies between some zoosporic fungi. Molecular and General Genetics 136, I 5 I-I 65.

REYNOLDS, E. S. (1963). The use of lead citrate at high $\mathrm{pH}$ as an electron-opaque stain in electron microscopy. Journal of Cell Biology 17, 208-21 2.

Sansing, G. A., Detroy, R. W., Freer, S. N. \& Hesseltine, C. W. (1973). Virus particles from conidia of Penicillium species. Applied Microbiology 26, 914-918.

Schisler, L. C., Sinden, J. W. \& Sigel, E. M. (1967). Etiology, symptomatology, and epidemiology of a virus disease of cultivated mushrooms. Phytopathology 57, 519-526.

Spurr, A. R. (1969). A low-viscosity epoxy resin embedding medium for electron microscopy. Journal of Ultrastructure Research 26, 3I-43.

Turian, G. (1963). Synthèse différentielle d'acide ribonucléique et différenciation sexuelle chez l'Allomyces. Developmental Biology 6, 6I-72.

WATSON, M. L. (1958). Staining of tissue sections for electron microscopy with heavy metals. Journal of Biophysical and Biochemical Cytology 4, 475-478.

YAmAshita, S., DoI, Y. \& YORA, K. (I973). Intracellular appearance of Penicillium chrysogenum virus. Virology 55, 445-452. 